\title{
Capacitating national research: a review of South African natural sciences research projects, theses and dissertations, 1986-2006
}

\author{
Omwoyo Bosire Onyanchal \\ University of South Africa, Dept of Information Science, South Africa \\ onyanob@unisa.ac.za orb_onyancha@yahoo.com \\ Daisy Jacobs ${ }^{2}$ \\ University of Zululand, Department of Information Studies, South Africa \\ daisymjacobs@yahoo.com
}

\begin{abstract}
Received: 10 October 2008
Accepted: 20 November 2009

The paper examines selected natural sciences research output in South Africa, with special reference to research projects, theses and dissertations in order to determine the trends and nature of capacitation of national research in the selected disciplines in the country. Relevant data was extracted from the South African Bibliographic and Information Network (SABINET)-hosted Current and Completed Research (C\&CR) database using subject codes as well as subject keywords. The study reveals that the trends of capacitating national research in natural sciences in South Africa follows a mixed pattern of growth, biology is the most researched subject/discipline, co-supervision of research projects in South Africa is minimal, universities are the main centres for capacitating national research, interdisciplinary and multidisciplinary research is visible, research capacity building is largely at the level of Masters degree and English language is the most commonly used language of capacitation of national research. In conclusion, we argue, among other recommendations, that there is a need to convert the completed research projects (that is, technical reports, dissertations, theses and so on) into publishable research articles for wider dissemination of research findings.
\end{abstract}

Keywords: Informetrics, natural sciences, research, South Africa

\section{Introduction}

Access to research output by scientists and researchers is of vital importance in any given geographical region, including the African continent which is challenged with so many development needs; so urgent are Africa's needs that the effective dissemination of this knowledge is to a certain extent a matter of life and death. Africa is undergoing one of its worst phases as it faces the overwhelming challenges of providing food and health services to its people who are plagued with HIV/AIDS pandemic. The continent is facing mass unemployment which has hampered its much needed economic growth. Most of the countries in Africa belong to the least developed countries category.

Gray (2007) reckons that in the process of confronting these and other challenges, African universities with the exception of South Africa which faces its own post-apartheid challenges, find themselves handicapped by decades of structural adjustment programmes, starved of resources, struggling to retain staff and scarcely able to carry out research, let alone publish or disseminate it. The university system across sub-Saharan Africa, explains the same author, simply does not generate publications or disseminate research findings effectively enough to reach the audiences that need to make use of development-focused research from within the continent.

The use of foreign-based research outputs to inform decision making processes in the African continent is a common practice. This type of arrangement was praiseworthy in times gone by, say the Commission on Intellectual Property Rights (CIPR 2002) and the United Nations Educational, Scientific and Cultural Organization [UNESCO] (2005), but does not address the question of the production and growth of research output from African universities. Very often African research knowledge is either locked inside international publications that are too expensive for African university libraries and scholars, or published in local journals that are relegated to the second rank by a global system that does not value them. In this way, African knowledge is marginalised in and through the systems, policies and hierarchies that govern the global research publication system and the end result is that it ignores the knowledge that is produced from Africa and its value which is considerable.

According to Bloom, Canning \& Chan (2005) the attitude to African higher education is slowly changing and there is a definite emphasis on research in science and technology and publication in peer reviewed journals. This view is supported

I. Omwoyo Bosire Onyancha (PhD) is a senior lecturer at the University of South Africa in the Department of Information Science, Pretoria, South Africa.

2. Daisy Jacobs $(\mathrm{PhD})$ is a senior lecturer at the University of Zululand in the Department of Information Studies, South Africa. 
by Gevers \& Mati (2006) who explain that the strategic approach to research publishing in South Africa produced by the Academy of Science and commissioned by the Department of Science and Technolgy is a sure indication that there is commitment among South African policy-makers to begin to deal with the question of research dissemination. The strategic approach to research, published by the Academy of Science of South Africa (ASSAf), provides a detailed account of the state of scholarly publishing in South Africa, especially on accredited publications.

King (2004) points out that research and dissemination through scholarly journals is skewed with the top four countries in the list of most-cited articles producing 84 per cent of the articles. He further states that a careful study of the citation impact showed that the $3 \mathrm{I}$ countries selected for the survey account for 97.5 per cent of the world's most cited papers, while 163 other countries, mostly developing countries combined together produce the other 2.5 percent. Authors such as King (2004), Chan and Costa (2005) and Willinsky (2006) agree that there is great disparity between the first and second divisions in the scientific impact of nations. The only country that has come up in King's study is South Africa which in 2000 was ranked 29 out of 31 countries and had just 0.5 per cent of the articles in the combined Thomson Scientific databases and 0.15 percent of the most cited papers (King 2004, Gevers \& Mati 2006). This figure according to Department of Arts, Culture, Science and Technology (DACST 2002), has further declined in the last decade. Thomson Scientific databases have been criticised in strong terms by Steele, Butler and Kingsley (2006) and Nwagwu (2005, 2007a, 2007b) for their bias and uneven coverage of journals written in languages other than English. The bias in the disciplinary fields reflected in the Thomson-indexed journals emerges very clearly in an analysis of the South African journals in these databases; none of the accredited South African humanities journals and only two out of 21 locally accredited social science journals are listed in the Thomson indexes. Gevers \& Mati (2006) say that in social sciences and humanities only a small percentage of journal articles are published in Thomson-indexed journals.

Work produced by South African and other African authors are at times considered to be lacking the required quality in comparison to the work done by the authors from the developed world and hence the African scientists are encouraged to work harder to ensure that their research and publications are of high quality and can match any publications output from the developed world. This will enable them to publish their work not only in the local journals but in any international journal which are indexed by Thompson Reuters, formerly known as the Institute of Scientific Institution (ISI). According to Meadows (1974), the doctorate is considered as a union card for scholarly research and can serve as a yardstick of research manpower in developed countries such as the United States and other countries with similar educational systems. And Price (1986) supports this idea when he adds that this kind of research provides a relatively straight forward indication of scholarly growth and research and that quantitative studies of degrees awarded are of great value to researchers who are looking for trends which can be used to predict the future growth or decline in scholarship.

Writing a Masters or $\mathrm{PhD}$ thesis or dissertation and defending it out of an original research provides the author the official entrance into the scientific world of research and knowledge. This further gives recognition to the new scientist from his mentors and peers alike and confirms the researcher's status as a member of the chosen scientific field (Lariviere, Zuccala \& Archambault 2008). Although doctorate has existed since the middle ages, it was only at the beginning of $19^{\text {th }}$ century that the PhD degree became a diploma associated to the production of original scientific research. And now these theses and dissertations can be accessed from websites as they are published by students very often in their own websites.

In South Africa this mode of publication of theses for general use is limited. The original 21 universities of higher learning belonged to three categories; namely, the well developed traditionally white universities, the historically disadvantaged black universities and the three universities which belonged neither to these two categories. But for the past few years, after the merger of universities either with each other or with the well established technikons, the number of higher institutions in the country has become twenty three. There is a greater emphasis on research and development among the policy makers and funding agencies like the National Research Foundation (NRF) for training and development of research among the young and budding scientists. A large amount of funding is allocated for research among the masters and doctoral students, especially those in science. It is considered of utmost importance at this juncture to make a quantitative evaluation of the theses and dissertations of masters and doctoral students from the higher institutions of the country. A study of this nature and results obtained will be an eye opener to the funding agencies, policy makers and the government about the real situation as far as research and publication in science is concerned.

This paper therefore seeks to investigate the entire period from 1986 to 2006 and all the projects, theses and dissertations that were published during this period in order to observe the trends in research experienced thereby serving as an indicator of the capacitation of research in South Africa. This study compares research projects produced one decade before the end of apartheid and one decade in the post-apartheid South Africa; i.e. 1986 to 1994, the period 
before the democratic election (still apartheid period) and the latter period from 1995 to 2006 after the scientific embargo on the country was removed.

\section{Methods and materials}

This study employed informetric approaches to examine the trends of research in South African universities, with special reference to theses, dissertations and other research projects as indexed in the Current and Completed Research (C\&CR) database. The C\&CR database is one of the databases published by the South African Bibliographic and Information Network (SABINET). It indexes masters and doctoral theses and dissertations of South African universities, and technikons as well as information on research projects from non-governmental organizations, private sector and government departments in the subject fields of sciences, humanities, economic and management sciences. The database is updated monthly and covers materials published since 1950.

In order to extract relevant data from the database, we identified three broad fields of natural sciences, namely, life sciences, earth sciences and physical sciences from the online version of Britannica Encyclopaedia ${ }^{3}$. Each broad field was then explored in order to select more specific terms with which the searches were conducted. The following hierarchical tree (Figure I) shows the areas covered in this study as well as terms used to extract the data from C\&CR.
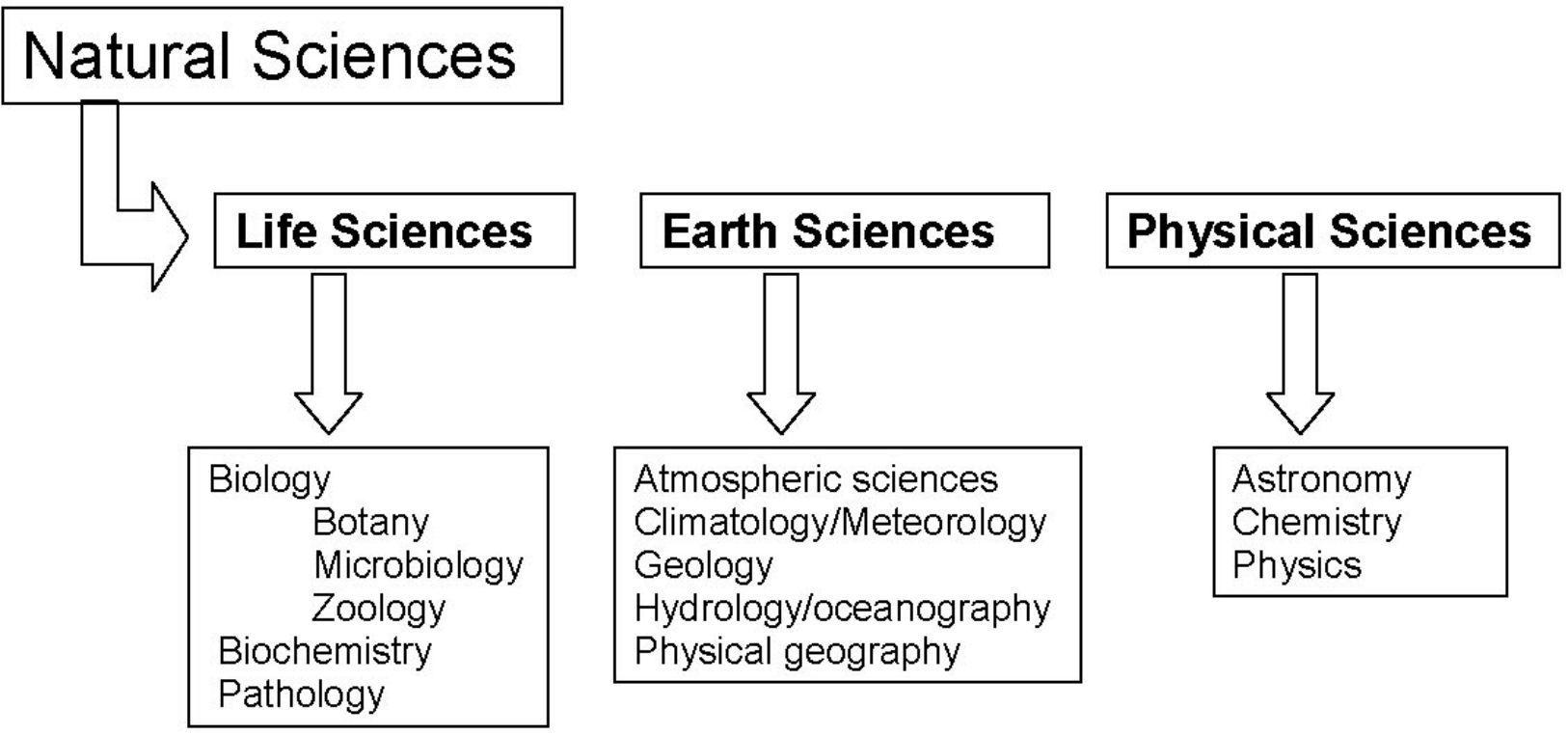

Figure 1 Areas covered and terms used to extract the data

Using the advanced search mode, searches were conducted within the 'subject' or 'subject phrase' fields. As the term 'biology' is not one of the subject indexing terms in C\&CR database, we used three specific subject terms (i.e. botany, microbiology and zoology) to download records on biology. The searches were limited to theses, dissertations and projects completed between 1986 and 2006. The extracted data was saved as text (*.txt) files as this format is readily compatible with the software that was used to analyze the data.

\subsection{Preparation of data for analysis using BIBEXCEL}

The preparation of records for analysis involved the removal of duplicate records and irrelevant data (e.g. record number, abstract and indexing agency, subject code, etc.), and removal of unnecessary Hard Returns $<H R>$ which are not acceptable by BIBECEL software. The downloaded record contained the following data: record number; title; translated title (if original title was in Afrikaans); name of database from which the record was downloaded; name(s) of author(s); institutional affiliation of author(s); year of completion of project; subject(s); intended publication; notes (purpose of study); status of research project; the abstract; language in which the report was written; and the indexing agency. The following is an example of the information contained in the downloaded record.

I I. Marked Record from Search: su: (geology)

3. http://www.britannica.com/eb/subject?idxStructld $=406348$

SA Jnl Libs \& Info Sci 2009, 75(2) 
Title: Die Witpoortjieverskuiwing

Translated Title: The Witpoortjie fault

Database: Current \& Completed Research

Name: Van Coller

SW

Institution: Rand

Afrikaans University

Year Completed: 1989

Subjects: Geology

Subject Code: 27200

Intended Publication: Dissertation

Notes: Purpose: MSc, Completed

Language: Afrikaans

Indexed by: NRF

It is noticeable that this record contains unnecessary data, e.g. alternative title, name of database, subject code, and indexing agency. Again, in some cases, the author(s)' and institutional names ran into two rows and as the Software would treat the two rows as separate entries, it was necessary to format the name(s) of author(s) and institution(s) to fit into one but separate line. Using the above example, all records were edited so as to contain only relevant data for the current study as well as conform to the specifications of the Software that was to be used for data analysis as follows:

Translated Title: The Witpoortjie fault

Name: Van Coller SW

Institution: Rand Afrikaans University

Year Completed: 1989

Subjects: Geology

Intended Publication: Dissertation

Notes: Purpose: MSc, Completed

Language: Afrikaans

This data was then subjected to analysis using BIBEXCEL computer-aided software, which generated frequencies for each field (i.e. title, name(s) of authors, year of project completion, subjects, intended publication, notes, and language). The analyzed data was then exported from BIBEXCEL to Microsoft Excel software which was also used to present the findings in graphics. The integer count approach was adopted to assign frequencies to different variables. Unlike the fractional approach of counting records, in the integer count approach (sometimes referred to as complete count), the rule is to count every item or unit of analysis (e.g. author, language, institution, country, subject, etc.) whether that item description appears one or multiple times in one record (see Diodato, 1994:48). For instance, assuming that the above example contained both dissertation and thesis as 'intended publication'. Then, each publication will be counted once; thus:

\begin{tabular}{|l|l|}
\hline Type of publication & No. of records \\
\hline Dissertation & $\mathrm{I}$ \\
\hline Thesis & $\mathrm{I}$ \\
\hline
\end{tabular}

\section{Results and discussion}

3.1 Distribution of records by year of completion

Table I shows the trend of production of research projects (including masters and doctoral research) in various natural science disciplines/fields in South Africa from 1986 to 2006. In a way, this trend reflects the pattern of research capacity building in the institutions of higher learning and others in selected natural sciences in South Africa. Evidently, there has been a mixed pattern of growth in the number of publications with Zoology leading the pack. There were a total of 1767 research projects in Zoology that were completed between 1986 and 2006, followed by Chemistry (2023), Botany (1282), Physics (926) and Microbiology (846). It was noted that among the three categories of natural sciences, Life Sciences - and more particularly Biology and Biochemistry - performed better than the other two categories, i.e. Physical 
sciences and Earth sciences. Biology is making rapid strides on many fronts as it has become interdisciplinary and the research in this area is edging its way to the centre stage, dislodging physics. The least researched disciplines or fields of natural sciences is atmospheric science and astronomy which recorded a total of only 9 and 25 records, respectively.

Table I Distribution of records by year of completion and discipline

\begin{tabular}{|c|c|c|c|c|c|c|c|c|c|}
\hline \multirow[t]{2}{*}{ Broad Field } & \multirow[t]{2}{*}{ Discipline/Subject } & \multicolumn{8}{|c|}{ Year of Completion } \\
\hline & & $\begin{array}{c}1986- \\
1988\end{array}$ & $\begin{array}{l}1989- \\
1991\end{array}$ & $\begin{array}{c}1992- \\
1994\end{array}$ & $\begin{array}{c}1995- \\
1997\end{array}$ & $\begin{array}{l}1998- \\
2000\end{array}$ & $\begin{array}{l}2001- \\
2003\end{array}$ & $\begin{array}{l}2004- \\
2006\end{array}$ & TOTAL \\
\hline \multicolumn{10}{|l|}{ Life sciences } \\
\hline & Biology & & & & & & & & \\
\hline & Zoology & 219 & 254 & 285 & 276 & 262 & 280 & 191 & 1767 \\
\hline & Botany & 151 & 212 & 207 & 176 & 182 & 206 & 148 & 1282 \\
\hline & Microbiology & 91 & 92 & 111 & 144 & 133 & 153 & 122 & 846 \\
\hline & Biochemistry & 78 & 66 & 108 & 103 & 128 & 156 & 155 & 794 \\
\hline & Pathology & $\mathrm{I}$ & 7 & 5 & 10 & 7 & 12 & 12 & 54 \\
\hline \multicolumn{10}{|c|}{ Physical sciences } \\
\hline & Chemistry & 207 & 249 & 280 & 301 & 280 & 339 & 367 & 2023 \\
\hline & Physics & 127 & 143 & 143 & 112 & 143 & 114 & 144 & 926 \\
\hline & Astronomy & 0 & 4 & 4 & 5 & 8 & 2 & 2 & 25 \\
\hline \multicolumn{10}{|l|}{ Earth sciences } \\
\hline & Geology & 126 & 120 & 127 & 125 & 112 & 80 & 77 & 767 \\
\hline & Physical geography & 0 & 1 & 29 & 16 & 19 & 32 & 36 & 133 \\
\hline & Hydrology/oceanography & 15 & 17 & 15 & 10 & 20 & 18 & 24 & 119 \\
\hline & Climatology/Meteorology & 6 & 6 & 10 & 10 & 8 & 10 & 19 & 69 \\
\hline & Atmospheric science & 0 & 0 & 0 & 5 & 3 & I & 0 & 9 \\
\hline
\end{tabular}

\subsection{Distribution of records by nature of supervision}

South African institutions of higher learning, and in particular the universities, are increasingly encouraging strong menteementor relationships. This relationship takes many forms, one of which is a situation where senior researchers collaborate with junior colleagues in the supervision of masters or doctoral projects. Although this type of relationship could not be established for lack of information in the data collected in this study, Fig 2 reveals that supervision of projects by one study leader was the most common. There were a total of 1793 projects singly supervised while two-study leader projects were 807 . The number of projects that were co-supervised by three, four and five study leaders each totalled 75, 7 and I respectively. Evidently, the number of projects falls as the number of study leaders co-supervising a given project increases. There were very few projects that were co-supervised by 4 study leaders and even a fewer number that was supervised by 5 study leaders. Does this imply that there is a point beyond which the number of study leaders for a single project cannot go? Joint supervision of projects can be a daunting task especially if the study leaders have opposing views. There are situations where each supervisor (especially where both supervisors are senior colleagues) would instruct the student differently about a similar issue, thereby confusing the student. In such situations (and seniorjunior relationship), the main supervisor normally would make a final decision. Other challenges faced by joint supervisors include the turnaround time within which a student receives feedback. It is common to find that there are delays on the part of one or more supervisors. So, what is an ideal number of joint supervisors for any project? Literature is silent on this issue. Nevertheless, the current study indicates that on average the number of study leaders for any given cosupervised project is between 2 and 3 . 


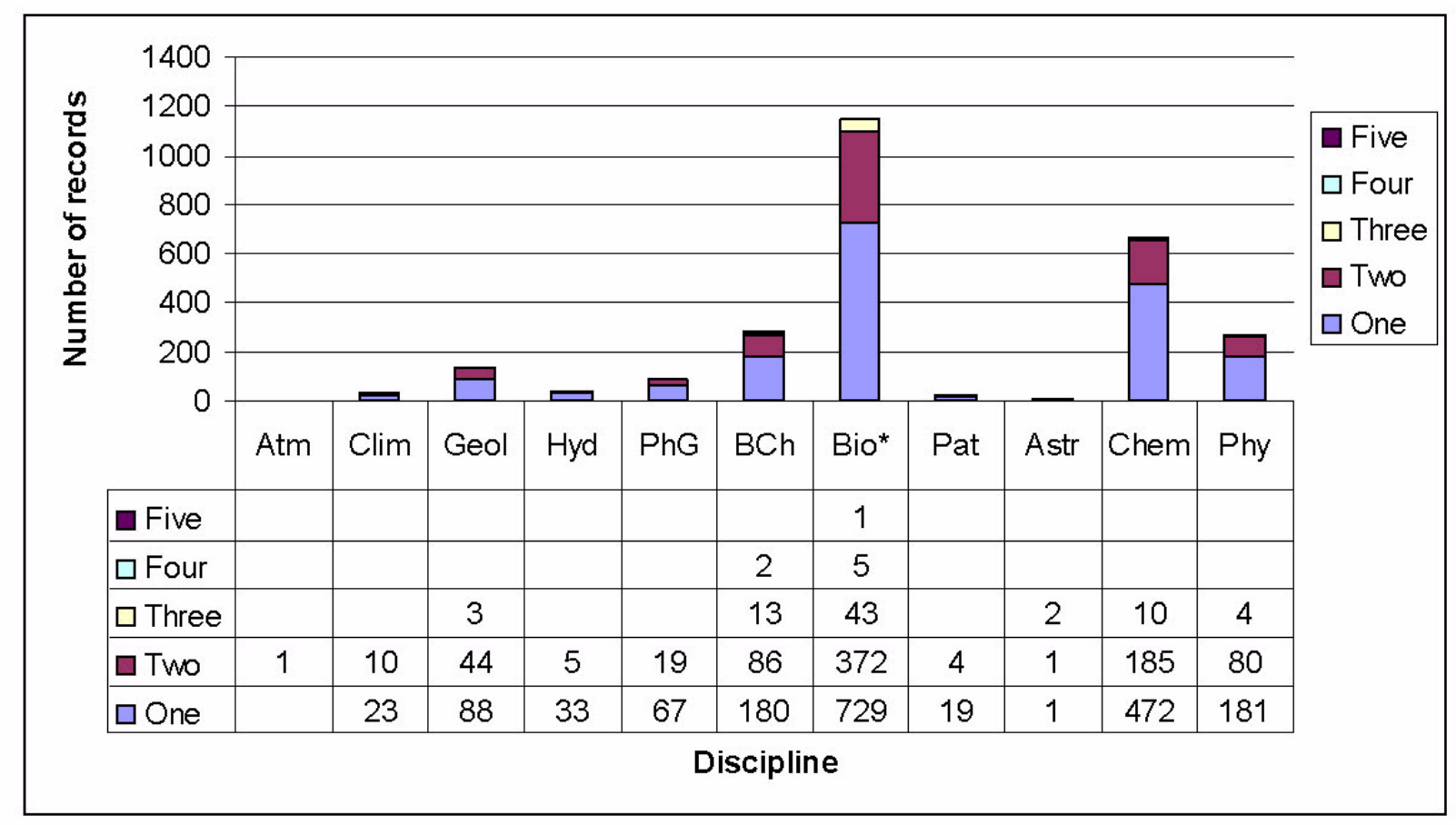

Figure 2 Co-supervision of research projects in natural sciences, 1986-2006

\subsection{Distribution of records by institution}

The distribution of projects by the author's institutional affiliation as shown in Table 2 indicates that the University of KwaZulu-Natal [UKZN] was the leading with I 162 records followed by the University of Pretoria [UP] (I I 39), University of Witwatersrand [WITS] (1042), University of Cape Town [UCT] (I0I7), Stellenbosch University [SUN] (879), University of the Orange Free State [UOVS] (723) and Rhodes University [RU] (673). As expected, universities occupied all the top positions. The other institutions that yielded at least one record and therefore participated in at least one research project include the Department of Environmental Affairs and Tourism (DEAT), Council of Scientific and Industrial Research (CSIR), Human Sciences Research Council (HSRC), MINTEK, MILPARK, the Agricultural Research Council of South Africa (ARCSA), and the National Research Foundation (NRF). It should be borne in mind that some of these institutions (e.g. NRF) support research through funding and, to a large extent, do not involve themselves (i.e. their staff) in the actual research and perhaps that explains why they seldom appear in a record's bibliographic information. For instance, it is acknowledged that NRF funds Masters and Doctoral students through such programmes as Thuthuka.

Another notable pattern in Table 2 is the dominance of Biology, Chemistry, Geology, Biochemistry and Physics in most institutions. It therefore implies that the core subjects/fields with regard to natural sciences in the most productive institutions of higher learning in South Africa are Biology, Chemistry, Geology, Biochemistry and Physics. Worth noting too is the fact that most productive institutions belong to what has become to be commonly referred to, in South Africa, as the Historically Advantaged Institutions (HAl). These institutions, namely, universities of Pretoria, Cape Town, KwaZuluNatal, Stellenbosch and Witwatersrand were well established with the relevant infrastructure for research and seasoned scientists and researchers. This pattern was also observed in previous studies (Onyancha, 2006; Jacobs, 2006). 
Table 2 Distribution of records by author's institution

\begin{tabular}{|c|c|c|c|c|c|c|c|c|c|c|c|c|}
\hline & \multicolumn{5}{|c|}{ Earth Sciences } & \multicolumn{3}{|c|}{ Life Sciences } & \multicolumn{3}{|c|}{ Physical Sciences } & \multirow[t]{2}{*}{ TOTAL } \\
\hline & Ast & Clim & Geol & Hyd & PhG & BCh & Bio* & Pat & Astr & Chem & Phy & \\
\hline UKZN & 1 & 5 & 89 & 15 & 20 & 84 & 562 & 3 & & 248 & 135 & 1162 \\
\hline UP & 5 & 16 & 101 & 2 & 5 & 74 & 610 & 14 & & 243 & 69 & 1139 \\
\hline WITS & & 21 & 104 & 9 & 9 & 87 & 380 & 11 & & 268 & 153 & 1042 \\
\hline UCT & & 12 & 130 & 22 & 19 & 42 & 463 & 18 & 19 & 197 & 95 & 1017 \\
\hline SUN & & 6 & 46 & 6 & 42 & 123 & 370 & 2 & 1 & 195 & 88 & 879 \\
\hline UOVS & 1 & 1 & 62 & 28 & 11 & 46 & 392 & 2 & & 137 & 43 & 723 \\
\hline$R U$ & & & 88 & 22 & 11 & 87 & 330 & & & 97 & 38 & 673 \\
\hline NMMU & & & 42 & & & 58 & 214 & I & & 190 & 78 & 583 \\
\hline UJ & 1 & 2 & 82 & 4 & 3 & 56 & 217 & & & 116 & 54 & 535 \\
\hline UNW & & & 12 & & & 79 & 172 & & 2 & 155 & 84 & 504 \\
\hline UWC & & & 5 & 6 & 5 & 14 & 82 & & & 67 & 37 & 216 \\
\hline UL & & & 2 & & & 16 & 28 & & & 17 & 15 & 78 \\
\hline UNISA & & & & & 1 & & & & 2 & 20 & 32 & 55 \\
\hline UFH & & & 2 & 1 & & 5 & 18 & & & 16 & 4 & 46 \\
\hline UNIZUL & & 5 & & 3 & & 6 & 11 & & & 9 & 7 & 41 \\
\hline MEDUSA & & & & & & 4 & 19 & 2 & & 3 & 1 & 29 \\
\hline TUT & & & & & & 3 & 1 & & & 20 & 1 & 25 \\
\hline DUT & & & & & & 5 & 3 & I & & 11 & 1 & 21 \\
\hline WSU & & & & & & 1 & 12 & & & 1 & 1 & 15 \\
\hline UNIVEN & & 1 & & & 2 & 3 & 3 & & & 3 & & 12 \\
\hline CPUT & & & & 1 & 2 & & & & & 4 & & 7 \\
\hline VUT & & & & & & & & & & 4 & & 4 \\
\hline CUT & & & & & & 1 & 2 & & & & & 3 \\
\hline Gov-DEAT & 1 & & & & & & 1 & & & & & 2 \\
\hline CSIR & & & 1 & & & & & & & 1 & & 2 \\
\hline HSRC & & & & & 2 & & & & & & & 2 \\
\hline MINTEK & & & 1 & & & & & & & & & I \\
\hline MILPARK & & & & & 1 & & & & & & & I \\
\hline Agr Res Council & & & & & & & 1 & & & & & I \\
\hline NRF & & & & & & & & & I & & & I \\
\hline SUB-TOTAL & 9 & 69 & 767 & 119 & 133 & 794 & 3891 & 54 & 25 & 2022 & 936 & 8819 \\
\hline TOTAL & & & 1097 & & & & 4739 & & & 2983 & & 8819 \\
\hline
\end{tabular}

* Biology includes Zoology, Botany, and Microbiology

3.4 Distribution of records by interdisciplinary studies

Interdisciplinary research involves an investigation of a phenomenon or problem that spans two or more disciplines. This ordinarily involves the participation of researchers belonging to and/or using research approaches from two or more disciplines. In this study, interdisciplinary studies were identified by examining the subject fields of each record and noting those records which contained two or more subject terms under this study's investigation, i.e. the selected subjects comprising the natural sciences. Fig. 3 reveals that apart from pathology and astronomy, each discipline had a link with at 
least one other discipline. Chemistry, which recorded the largest number of links (i.e. 5), was interlinked with Physics, Geology, Microbiology, Biochemistry and Botany. Its strongest link - demonstrated by the thickness of the line joining it with another discipline - was with Physics. Biochemistry, Botany, Microbiology and Zoology yielded 4 links each. In fact, most of the links belonging to these four disciplines are links to each other, thereby forming a cluster of some sort. For instance, $3 / 4$ of the total links are inter-linkages among the four disciplines, implying that only one link in each case goes to a discipline outside the four disciplines. Geology contained three links to Chemistry, Physical Geography and Hydrology/ Oceanography. Climatology/ Meteorology and Physics recorded two links each. Similarly, Physical Geography had links with three disciplines, namely Climatology/Meteorology, Geology and Hydrology/Oceanography. Whereas Physics contained a link each to Chemistry and Atmospheric Sciences, Climatology/Meteorology contained a link each to Physical Geography and Zoology. There is a strong interconnection between physics and environmental science and other related fields. The principles of physics are applied for the study of interactions between plants and animals and their environments. For example, in ecology and hydrology, concepts of atmospheric exchange of gases and energy between organisms and the atmosphere and the resistances controlling them are commonly applied. So in this way, physics has a strong link between all other branches of life and earth sciences.

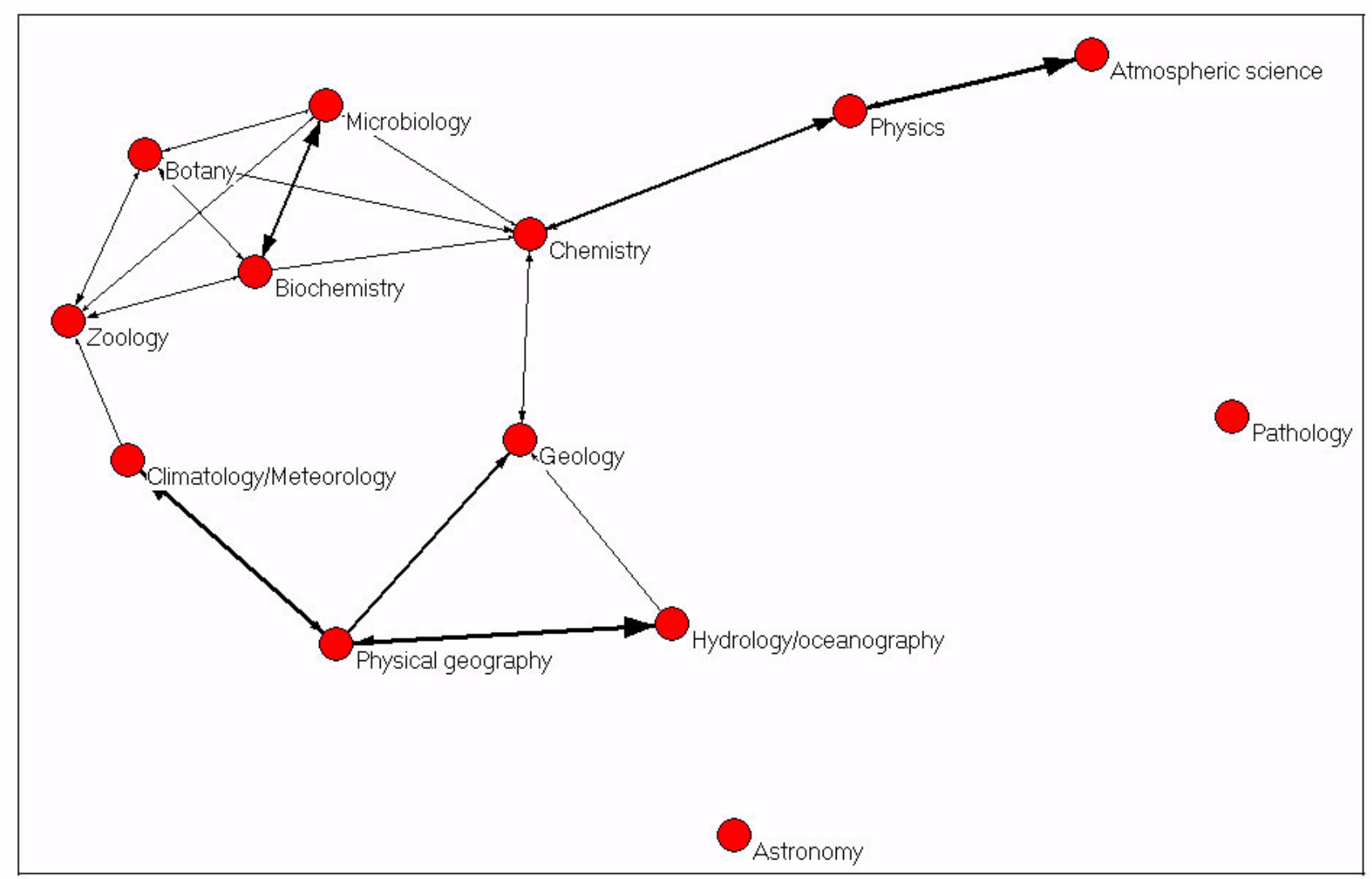

Figure 3 Interdisciplinary research in natural sciences

\subsection{Distribution of records by multidisciplinary studies}

The multidisciplinary nature of research in natural sciences research as reflected in research projects indexed in C\&CR database is shown in Table 3. This section highlights the largest contributing disciplines/fields in each of the natural science disciplines investigated. In the case of Biology (consisting of Zoology, Botany and Microbiology), Environmental sciences and ecology, Agriculture, Plant production, and Biochemistry yielded the highest number of records. Multidisciplinary research in Biochemistry witnessed strong links with Agriculture, Microbiology, Medical sciences and Botany. Research in Pathology covered two other disciplines/fields namely Medical sciences and Speech science while Hydrology/ Oceanography, Climatology/Meteorology and Agriculture formed the core of disciplines/fields discussed in Physical Geography research. Strong occurrences of Physical Geography, and Environmental sciences and ecology in Hydrology/ Oceanography research were noted. According to Jacobs (2004), multidisciplinary studies may be used to examine how 
particular fields/subjects contribute/borrow theories and methods to/from others. Multidisciplinary nature of research may also be an indicator of collaboration among researchers from different subject/field orientation.

Table 3 Multidisciplinary research in natural sciences

\begin{tabular}{|c|c|c|}
\hline Broad Field & Discipline/Subject & Disciplines/Fields co-researched \\
\hline \multicolumn{3}{|l|}{ Life sciences } \\
\hline & Biology & \\
\hline & Zoology & $\begin{array}{l}\text { Environmental sciences and ecology (78), Agriculture (22), Veterinary science (3), Animal production (2), } \\
\text { Biochemistry (2), Biotechnology (2), Botany (2), Genetics (2), Mathematics, mathematical statistics and } \\
\text { statistics (2), Medical sciences (I), Microbiology (I), Physiology and anatomy (I), Climatology (I) }\end{array}$ \\
\hline & Botany & $\begin{array}{l}\text { Environmental sciences and ecology (I8), Agriculture (I3), Plat production (I3), Biochemistry (4), } \\
\text { Genetics (2), Horticulture (2), Soil sciences (2), Medical sciences (2), Microbiology (2), Education (I), } \\
\text { Zoology (I), Biotechnology (I), Chemistry (I) }\end{array}$ \\
\hline & Microbiology & $\begin{array}{l}\text { Biochemistry (I3), Agriculture (7), Environmental sciences and ecology (3), Biophysics (I), Botany (I), } \\
\text { Chemistry (I), Food science and technology (I), Medical sciences (I), Plant production (I), Zoology (I) }\end{array}$ \\
\hline & Biochemistry & $\begin{array}{l}\text { Agriculture (42), Microbiology (I3), Medical sciences (5), Botany (4), Biotechnology (2), Zoology (2), } \\
\text { Biophysics (I), Chemistry (I), Environmental sciences and ecology (I), Genetics (I), Veterinary science (I) }\end{array}$ \\
\hline & Pathology & Medical sciences (47), Speech science (7) \\
\hline \multicolumn{3}{|c|}{ Physical sciences } \\
\hline & Chemistry & $\begin{array}{l}\text { Botany (2), Education (2), Environmental sciences and ecology (2), Energy (2), Geology (2), Physics (2), } \\
\text { Microbiology (I), Business Administration (I), Biotechnology (I), Biochemistry (I), Agriculture (I) }\end{array}$ \\
\hline & Physics & $\begin{array}{l}\text { Mathematics, mathematical statistics and statistics (7), Chemistry (2), Science and technology (I), Medical } \\
\text { sciences (I), Environmental sciences and ecology (I), Education (2), Atmospheric sciences (I) }\end{array}$ \\
\hline & Astronomy & Mathematics, mathematical statistics and statistics (2) \\
\hline \multicolumn{3}{|l|}{ Earth sciences } \\
\hline & Geology & $\begin{array}{l}\text { Archaeology (8), Environmental sciences and ecology (3), Geophysics (3), Mining engineering (3), Physical } \\
\text { geography (3), Chemistry (2), Human and regional geography (I), Hydrology/oceanography (I) }\end{array}$ \\
\hline & Physical geography & $\begin{array}{l}\text { Hydrology/oceanography (103), Climatology/meteorology (67), Agriculture (4), Geology (3), Medical } \\
\text { sciences (2) }\end{array}$ \\
\hline & $\begin{array}{l}\text { Hydrology/ } \\
\text { oceanography }\end{array}$ & $\begin{array}{l}\text { Physical geography (I03), Environmental sciences and ecology (I2), Agriculture (I), Geology (I), } \\
\text { Mathematics and statistics (I) }\end{array}$ \\
\hline & $\begin{array}{l}\text { Climatology/ } \\
\text { Meteorology }\end{array}$ & Physical geography (67), Environmental sciences and ecology (I), Zoology (I) \\
\hline & Atmospheric science & Agriculture (I), Physics (I) \\
\hline
\end{tabular}

Table 4 Distribution of records by language of publication

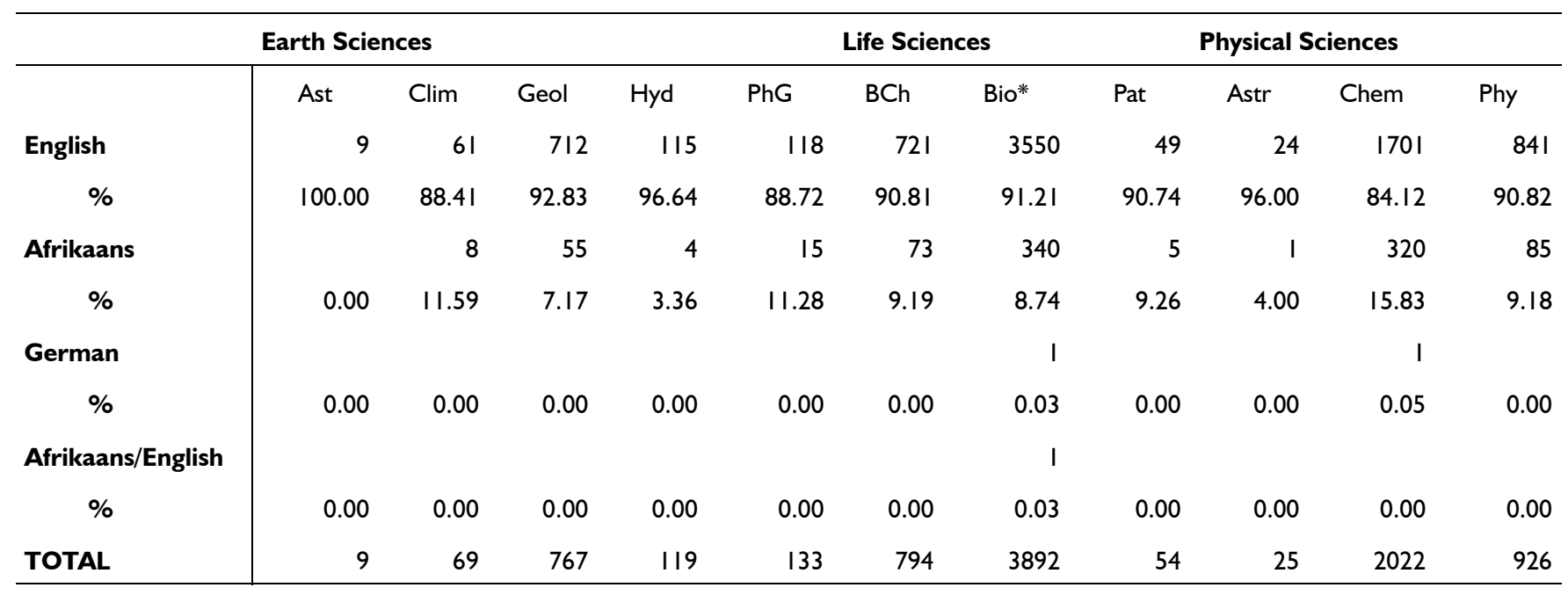


3.6 Distribution of records by language

The language in which a research project is written is an important factor in the dissemination and use of research findings. Language determines the visibility and impact of the research publication, be it a dissertation/thesis, research article, or technical report. An analysis of the records by the language of publication reveals that English was the dominant language throughout the disciplines. Apart from Chemistry whereby the number of records written in English was below $85 \%$, the rest of the disciplines recorded as high percentages as $96.6 \%$ in favour of English language. Afrikaans was the second most commonly used language to publish research projects. German came a distant third while there was only one record which was published in both English and Afrikaans languages. This trend of publication in South Africa has been reported in previous studies (e.g. Ocholla, 2000; Onyancha, 2006) which noted preference of English language in the preparation of research projects in South Africa. The presence of German language as a language of publication of research projects in South Africa is indicative of research collaboration between Germany (German-speaking) and South African (most probably German-speaking) researchers. This report could have also been published by a German-speaking researcher who was in South Africa on an exchange visit.

3.7 Distribution of records by intended publication

Table 5 provides intentions and intended publications in undertaking research projects in natural sciences in South Africa. At the top of the Table is Dissertation which yielded a total of 583I hits followed by Thesis (290I), Article/paper (5I), Report (35), Exchange visit (27), and Conferences, workshops and seminars (II). In total there were 16 unique research intentions/intended publications. Apart from the aforementioned, others are: Training (9), Research report (6), Capacity building (5), Book chapter (4), Patents (2), Working paper (I), Tests (I), Products [such as antimalarial drugs] (I), Maps (I) and Lectures (I). Although not apparent in some of the intended publications in Table 5 such as Dissertations and Theses, we believe that capacity building should be the main aim underlying most research projects undertaken in South Africa. The unique items in Table 5 are intended to improve research output in the country.

Table 5 Distribution of records by the intended publication

\begin{tabular}{|c|c|c|c|c|c|c|c|c|c|c|c|c|}
\hline & \multicolumn{4}{|c|}{ Earth Sciences } & \multicolumn{3}{|c|}{ Life Sciences } & \multicolumn{4}{|c|}{ Physical Sciences } & \multirow[t]{2}{*}{ TOTAL } \\
\hline & Ast & Clim & Geol & Hyd & PhG & $\mathrm{BCh}$ & Bio* & Pat & Astr & Chem & Phy & \\
\hline Dissertation & 3 & 50 & 528 & 88 & 107 & 533 & 2631 & 29 & 14 & 1277 & 571 & 5831 \\
\hline Thesis & 4 & 50 & 230 & 31 & 19 & 238 & $124 \mid$ & 25 & 10 & 714 & 339 & 2901 \\
\hline Article/paper & I & & 4 & 1 & 3 & 9 & 17 & & I & 7 & 8 & 51 \\
\hline Report & 2 & & 5 & & I & 3 & 8 & & I & 8 & 7 & 35 \\
\hline Exchange visit & 2 & & I & & & 4 & 9 & & I & 3 & 7 & 27 \\
\hline Conferences, etc**** & & & & & & & 6 & & & 3 & 2 & II \\
\hline Training & & & & & & I & 4 & & & 2 & 2 & 9 \\
\hline Research report & & & 2 & & 2 & & & I & & & I & 6 \\
\hline Capacity building & & & & & & & 4 & & & I & & 5 \\
\hline Book chapter & & & 1 & & & & & & & 2 & I & 4 \\
\hline Patents & & & & & & & & & & 2 & & 2 \\
\hline Working paper & & & & & I & & & & & & & I \\
\hline Tests & & & & & & & & & & I & & 1 \\
\hline Products*** & & & & & & & 1 & & & & & 1 \\
\hline Maps & & & & & & & 1 & & & & & 1 \\
\hline Lectures & & & & & & & & & & & I & 1 \\
\hline
\end{tabular}

* Biology constitutes Botany, Microbiology and Zoology

**e.g. Antimalarial drugs

**** Conference, workshop or seminar papers 
3.8 Distribution of records by purpose of study

It is widely acknowledged that one is likely to become an active researcher once he/she attains a Masters Degree hence our analysis of completed Masters and Doctoral research projects as a way of examining the trends and level of capacitating national research in natural sciences in South Africa. Table 6 reveals that there are two purposes for which research is conducted in South Africa, namely: qualification and non-qualification. Non-qualification research would result in such deliverables and/or intended publications as research articles, reports, working papers, tests, products, maps, lectures, and conferences, workshops and seminars. Some of these deliverables could also be products of research projects that are intended for qualification, where qualification refers to an award of a certificate/degree.

Table 6 shows that the purpose of undertaking the majority of the research projects in natural sciences in South Africa was to receive a Masters Degree. The Master of Science yielded the highest number of records which totalled 5604 followed by the Master of Arts (65), Master of Technology (38), Master of Medicine (I2), Master of Philosophy (II), Master of Social Sciences (2), Master of Education (2), Master of Commerce (I), and Master of Business Administration (I).

Table 6 Distribution of records by purpose of study

\begin{tabular}{|c|c|c|c|c|c|c|c|c|c|c|c|c|}
\hline & \multicolumn{5}{|c|}{ Earth Sciences } & \multicolumn{3}{|c|}{ Life Sciences } & \multicolumn{3}{|c|}{ Physical Sciences } & \multirow[t]{2}{*}{ TOTAL } \\
\hline & Ast & Clim & Geol & Hyd & $\mathrm{PhG}$ & $\mathrm{BCh}$ & Bio* & Pat & Astr & Chem & Phy & \\
\hline MSc & 3 & 43 & 515 & 79 & 75 & 520 & 2585 & 10 & 14 & 1196 & 564 & 5604 \\
\hline $\mathrm{PhD}$ & 3 & 18 & 222 & 28 & 17 & 226 & 1169 & 26 & 10 & 675 & 322 & 2716 \\
\hline Non-Qualification & 3 & 1 & 9 & 1 & 7 & 23 & 38 & & I & 40 & 20 & 143 \\
\hline DSc & & & 8 & 2 & & 13 & 35 & & & 31 & 15 & 104 \\
\hline MA & & 6 & 11 & 6 & 24 & 3 & 8 & 3 & & I & 3 & 65 \\
\hline MTech & & & 2 & I & 2 & 7 & 8 & 2 & & 16 & & 38 \\
\hline DTech & & & & & & 1 & & & & 15 & & 16 \\
\hline M Med & & & & & & & & 12 & & & & 12 \\
\hline MPhil & & & & 2 & 1 & 1 & 4 & & & 2 & 1 & II \\
\hline MSocSci & & & & & 2 & & & & & & & 2 \\
\hline MEd & & & & & & & & & & 2 & & 2 \\
\hline MCom & & & & & I & & & & & & & I \\
\hline MBA & & & & & I & & & & & & & I \\
\hline D Med & & & & & & & & 1 & & & & I \\
\hline D Ed & & & & & & & & & & & I & I \\
\hline
\end{tabular}

The distribution of records according to the research projects completed for the award of doctoral degrees was as follows: Doctor of Philosophy (27I6), Doctor of Science (I43), Doctor of Technology (I6), Doctor of Medicine (I) and Doctor of Education (I).

One issue worth mentioning is the presence of such qualifications as Master of Arts, Master of Social Sciences, Master of Education, Master of Commerce, Master of Business Administration and Doctor of Education in natural science literature. It is not surprising, however, to find these qualifications indexed as intended purposes of research/study in natural sciences given the pattern witnessed in the multidisciplinary nature of research in Table 3 above. It is common to find social scientists conducting research on what many will refer to as natural science topics (e.g. HIV/AIDS, Malaria, Tuberculosis, etc) thereby necessitating these studies to be indexed in the natural science category of literature.

3.9 Funding of national research in South Africa

There is lack of data concerning the actual situation in regard to research funding in South Africa as each institution involved in research (e.g. universities, research councils and institutions) prepares individual research budgets. Further, the utilization of such funds is not often made public by respective institution, thereby unknown to the general public. This includes funds allocated for Masters and PhD studies. However, a general picture on the allocation of research funds in different disciplines by government of South Africa is reflected in Figure 4.

SA Jnl Libs \& Info Sci 2009, 75(2) 


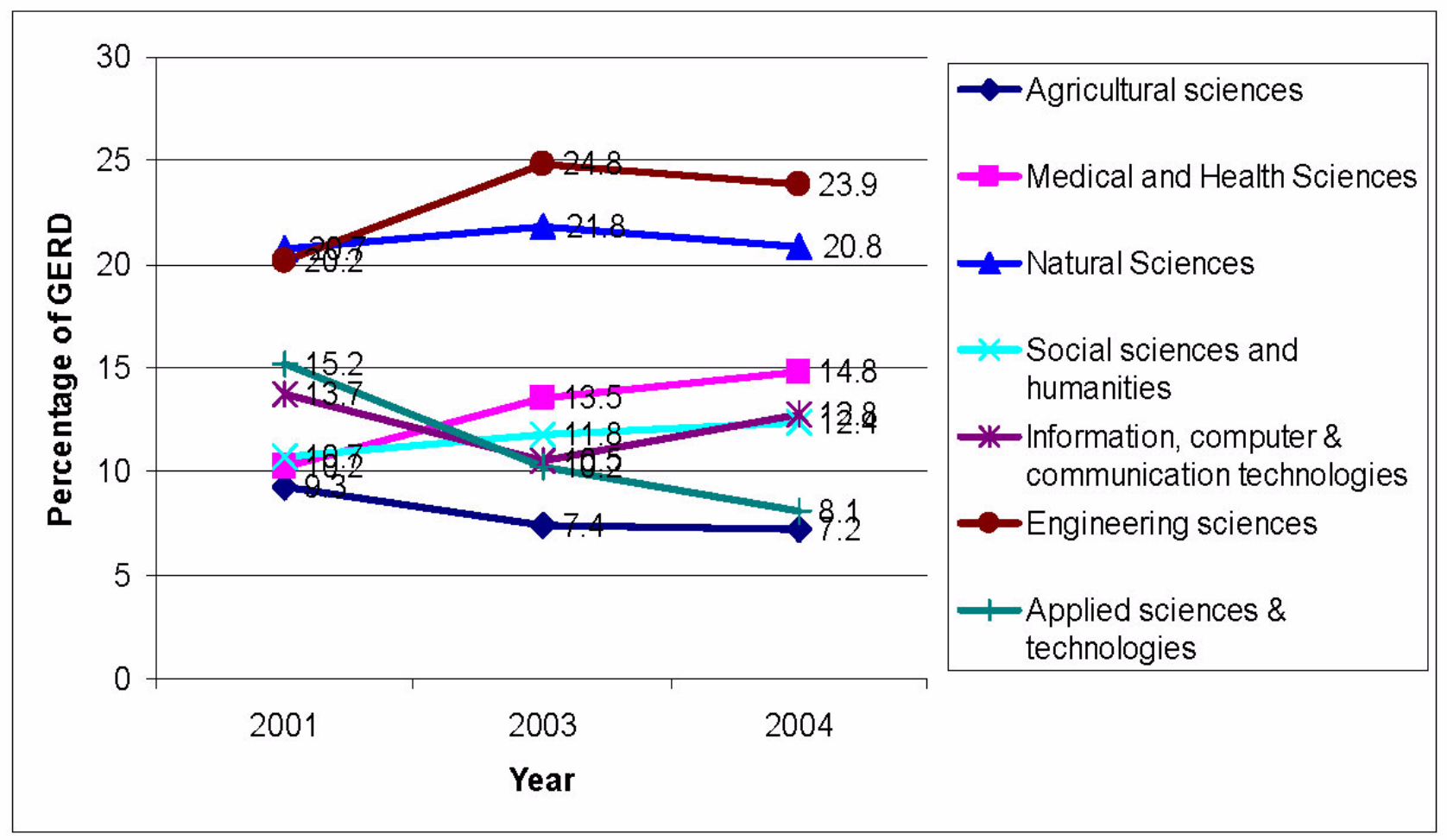

Figure 4 Expenditure on R\&D by major research field

(Source: Republic of South Africa: Department of Science and Technology, Annual Reports, 2002-2006)

GERD - Gross Domestic Expenditure on Research and Development

Evidently, natural sciences and engineering receives more funding from the government than does social sciences. Leading the pack is engineering sciences followed by natural sciences and medical and health sciences. The most focused on discipline in terms of research capacity building in South Africa is therefore engineering sciences and natural sciences. A breakdown of the natural sciences in order to ascertain which specific natural science receives which amount of funding was not possible at this stage.

\section{Conclusions and recommendations}

Generally, there is a low rate of growth in the number of researchers in natural sciences in South Africa as witnessed by the small numbers by which the records increased from one year to another. Further, the growth of researchers has not been consistent. This is shown by the up/down pattern of growth of records with some years producing fewer research projects than the previous years. This pattern is however likely to change as most universities in South Africa are encouraging their teaching staff to further their studies as well as get actively engaged in research for purposes of promotion and job tenure. Today, we see many advertisements for jobs that are placed in the media by universities for lectureship positions emphasizing that one should be enrolled for $\mathrm{PhD}$ as one of the requirements.

Most studies in natural sciences are largely supervised by one study leader each. There is little co-supervision thereby implying little collaboration among study promoters/leaders. This, in our view, impedes mentorship among researchers in institutions of higher learning. Co-supervision of research projects should be encouraged at all means. University administration should consider co-supervision of M\&D students by senior and junior researchers as one of the conditions for promotion and/or awarding researchers. Mentor-mentee relationship should go beyond tuition and research to incorporate joint supervision of research projects.

Obviously, universities are the most productive of research projects. This can be attributed to the fact that this study focused on Masters and Doctoral research projects which are ordinarily produced by students in universities. It was also noted that among the institutions, the Historically Advantaged Universities (HAUs) were the most productive. These institutions (traditionally white universities), according to Jacobs (2004) enjoyed support in terms of financial and quality human resources during the apartheid era thereby gaining a competitive edge over the previously black universities.

Although there were links (indicating relationships) among the surveyed natural science disciplines, the interdisciplinary research is weak in the country. For instance, there were only two occasions wherein the number of records 
that belonged to two or more disciplines surpassed 60. The rest of the interdisciplinary linkages produced less than I5 with some yielding as low as one record. Interdisciplinary research is important given that countries face a myriad of complex problems that cannot be solved by one approach. It requires a multi-pronged approach to solve most problems existing in South Africa and elsewhere in Africa. For instance, research on the HIV/AIDS pandemic may require the collaboration of physicians, biologists and even chemists to, for example, develop anti-retroviral and therapy drugs or even to discover a cure for HIV/AIDS.

There is evidence of multidisciplinary research in natural sciences. Of particular importance is the occurrence of social science disciplines in the natural science literature. This may be indicative of collaboration between social and natural scientists or the involvement of social scientists in the study of social issues related to natural science disciplines/topics. This brings on board multiple approaches to solving complex challenges faced by the citizenry as illustrated above. This in turn means that skills and knowledge are shared among the researchers, which indicates that researchers are empowering each other as far as imparting of knowledge and skills from researchers in a given discipline to those in another is concerned. There is need, however, to encourage this type of research in the country by awarding more funds to multidisciplinary research.

English and Afrikaans are the most commonly languages of publishing the research findings, with English language dominating. This trend is healthy for purposes of attracting a wider readership and thereby increasing international visibility impact. It also means that subsequent research outputs by the same researchers will be largely published in English language.

Dissertations and theses are the most published formats of research projects/outputs. Whether these outputs translate into research articles which are the most commonly used document types in disseminating research findings could not be concluded from the data obtained for this study. It is a pity that most theses and dissertations in South Africa remain unpublished. It is encouraging, however, to note that some universities in South Africa are taking initiatives to ensure that these outputs are converted into research articles. For instance, the University of KwaZulu-Natal recently advertised a job vacancy for a scientific editor whose responsibility, among others, was spelt out as follows:

The incumbent will draft scientific articles based on data published in dissertations and theses of postgraduate students and data collected by academic staff during research for non-degree purposes (Sunday Times, Business

Times section, 10 August 2008:6).

It is our recommendation that other universities should follow this example so that the research findings reported in the dissertations and theses can reach a wide audience. One other way of ensuring wider readership and therefore high impact of research is to self-archive these theses and dissertations in an Open Access Initiative (OAI)-compliant archive.

Notably, the focus areas of capacity building in research in South Africa include natural sciences and engineering, if the amount of funds allocated in each research field is anything to go by. Social sciences are among the least funded fields of research.

Majority of the researchers trained/produced at the South African institutions of higher learning are Masters Degree holders which implies that the process of capacitating national research in natural sciences is largely done at the Masters degree level. Doctorates are fewer. In its Key Performance Indicator Report of 2003/2004, the NRF (2008) states that capacity for research in South Africa is way far below what the country requires. The Foundation, in its mandate to improve this capacity, has outlined several strategies which include the following:

a. Provide open access to resources to all researchers, taking cognizance of their race and gender;

b. Adhere to quality research;

c. Internationalize research that is conducted by South African researchers by encouraging competition and collaboration with international researchers; and

d. Focus on Africa with special reference to working in collaboration with the New Partnership for Africa's Development (NEPAD) in order to create opportunities for special Research and Development (R\&D) initiatives.

Universities should be encouraged to adopt and/or implement some (or all) of these and other strategies in order to improve research capacity in the country. The more and quality researchers the universities produce, the stronger the country's research team.

\section{References}

Bloom, D., Canning, D. \& Chan, K. 2005 Higher education and economic development in Africa. Washington: World Bank.

Britannica Online Encyclopedia. 2008. Natural Science. [Online]: http://www.britannica.com/eb/subject?idxStruct/d=406348. Accessed 23 February 2008.

Chan , L. \& Costa, C. 2005. Participation in the global knowledge commons: challenges and opportunities for research dissemination in developing countries. New Library World, I06 I4I-I63.

SA JnI Libs \& Info Sci 2009, 75(2) 
CIPR (Commission on Intellectual Property rights). 2002. Integrating intellectual property rights and development policy. London: CIPR

DACST (Department of Arts, Culture, Science and Technology). 2002 South Africa's national research and development strategy. Pretoria: Government Publications Department.

Diodato, V. 1994. Dictionary of bibliometrics. New York: Haworth.

Gevers, W. \& Mati, X. (eds.). 2006 Report on strategic approach to research publishing in South Africa. Pretoria: Academy of Science of South Africa (ASSAf).

Gray, E. 2006. At the South-eastern frontier: the impact of higher education policy on African research publication. Unpublished conference paper, Codesria-ASC conference series 2006: Bridging the North South Divide in Scholarly communication: Threats and opportunities in the Digital Era, August 21-22, Leiden.

Jacobs, D. 2004. Growth and development in knowledge management research: a bibliometric study. In TJD Bothma \& A. Kaniki (eds). Proceedings of the $3^{\text {rd }}$ biennial DISSAnet Conference, Pretoria, 28-29 October 2004. Pretoria: Infuse, pp. 21 I-220.

Jacobs, D. 2008. An Informetric analysis of publication and research collaboration patterns in natural sciences in South Africa. South African Journal of Library and Information Science, 74(I):4 I-48.

King, D. 2004. The scientific impact of nations. Nature 43031 I-316.

Meadows, A.J. 1974. Communication in science. London: Butterworth

National Research Foundation (NRF). 2008. Key Performance Indicator Report 2003/2004. [Online]: http://www.nrf.ac.za/ publications/annrep/05/intro.htm. Accessed 4 November 2008.

Nwagwu, W.E. 2005. Deficits in the visibility of African scientists: implications for developing information and communication technology (ICT) capacity. World Review of Science, Technology and Sustainable Development, 2(3/4): 244-260.

Nwagwu, W.E. 2007a. Creating science and technology information databases for developing and sustaining Sub-Saharan Africa's indigenous knowledge. Journal of Information Science, 33:737-75I.

Nwagwu, W.E. 2007b. Cybernating the academe: centralization of science assessment as hegemony, an African alternative. In A Ahmed (ed). World sustainable development: knowledge and sustainable development in the 2 Ist century. London: Greenleaf Publishers, pp. 108-II9.

Ocholla, D.N. 2000. Research capacity in Library and Information Science in South Africa - an overview. Paper delivered at the 66th IFLA Council and General Conference, Jerusalem, Israel, I3th- I8th August 2000. [Online]: http://www.ifla.org/IV/ifla66/ papers/054-127e.htm. Accessed I4 February 2008.

Onyancha, O.B. 2006. Empowering the South African community in the AIDS war: an informetric-case study of HIV/AIDS research projects, with special reference to masters and doctoral dissertations and theses. South African Journal of Libraries and Information Science, 7I(2):56-7I.

Price, de Solla, D. J. 1986. Little science, big science... and beyond. New York: Columbia University press: pp. 46-I56.

Steele, C., Butler, L. \& Kingsley, D. 2006. The Publishing Imperative: the pervasive influence of publication metrics. Learned Publishing, 19 (4):277-290

Sunday Times [Business Times]. 2008. Scientific editor [Advertisement by the University of KwaZulu-Natal, South Africa]. 10 August 2008, pp. 6

Willinsky, J. 2006. The access principle: the case for open access to research and scholarship. Cambridge, MA: MIT Press 